\title{
Pertanggung Jawaban Hukum Bagi Notaris Atas Tindak Pidana Yang Dilakukan Oleh Karyawan Notaris
}

\section{Mayrsha Ayu Khairina}

Program Magister Kenotariatan Fakultas Hukum Universitas Islam Indonesia Yogyakarta Indonesia Jln. Cik Di Tiro No. 1 Yogyakarta 55283 Indonesia mayrsha.ayu@gmail.com

\begin{tabular}{|c|c|}
\hline Key Word: & Abstract \\
\hline $\begin{array}{l}\text { Forgery of letter; } \\
\text { notary's employee; } \\
\text { notary responsibility }\end{array}$ & $\begin{array}{l}\text { This study aims to analyze and identify the form of the notary's responsibility as a } \\
\text { leader against criminal acts committed by the notary's employees? and the legal } \\
\text { protection of a notary against criminal acts committed by notary employees? This } \\
\text { is a normative research, supported by primary data in the form of Law Number } 2 \\
\text { of } 2014 \text { concerning Notary Positions and related court decisions as well as } \\
\text { secondary data in the form of integrated interviews with sources from } \\
\text { practitioners and academics. The approach taken by the author is a legal approach } \\
\text { and a case approach which is described in a qualitative descriptive manner. The } \\
\text { results of this research conclude that firstly, if a notary's employee commits a } \\
\text { criminal act of forging a letter which results in a defect in the authentic deed or a } \\
\text { loss for a third party, then it is possible that the notary can be held responsible for } \\
\text { this as in the crime of participation contained in Article 55 Jo. Article } 263 \\
\text { paragraphs (1) and (2) of the Criminal Code. Second, there are forms of legal } \\
\text { protection provided by the law, namely from the Notary Honorary Council and } \\
\text { self-protection }\end{array}$ \\
\hline
\end{tabular}

Kata-kata Kunci:
Pekerjar notaris;
pemalsuan surat;
pertanggungjawaban
notaris

\section{Abstrak}

Penelitian ini bertujuan untuk menganalisis dan mengetahui bagaimana bentuk pertanggungjawaban notaris sebagai pimpinan terhadap tindak pidana yang dilakukan oleh karyawan notaris? serta bagaimanakah perlindungan hukum notaris atas tindak pidana yang dilakukan oleh karyawan notaris? Penelitian ini adalah penelitian normatif. Didukung dengan data primer yang berupa Undang-Undang Nomor 2 Tahun 2014 tentang Jabatan Notaris dan putusan pengadilan terkait serta data sekunder berupa wawancara terpadu dengan narasumber yang berasal dari praktisi dan akademisi. Pendekatan yang dilakukan oleh penulis ialah dengan pendekatan undang-undang (statue approach) dan pendekatan kasus yang dijelaskan secara deskriptif kualitatif. Hasil penelitian ini menyimpulkan, pertama, bilamana karyawan notaris melakukan tindak pidana pemalsuan surat yang mengakibatkan cacatnya akta otentik atau kerugian bagi pihak ketiga, maka tidak menutup kemungkinan notaris dapat dipertanggungjawabakan atas hal tersebut sebagaimana dalam tindak pidana penyertaan yang termuat dalam Pasal 55 Jo. Pasal 263 ayat (1) dan (2) KUHP. Kedua, bentuk perlindungan hukum yang diberikan oleh Undang-Undang, yakni dari Majelis Kehormatan Notaris dan perlindungan diri sendiri.

\section{Pendahuluan}

Notaris dalam menjalankan jabatannya dapat dibantu atau dapat memperkerjakan pihak-pihak tertentu sesuai dengan kriteria dan kebutuhan yang diperlukan. Keterlibatan karyawan kantor notaris bila penulis deskripsikan dengan sederhana yakni pembuatan akta secara teknis dalam artian menyiapkan akta-akta yang telah dikonsep oleh notaris, 
kemudian merapikan berkas-berkas akta, mengkomunikasikan dengan pihak atau klien, atau seperti dalam ketentuan Pasal 16 Undang-Undang Nomor 2 Tahun 2014 tentang Jabatan Notaris (selanjutnya disebut sebagai UUJN).

Bertalian dengan hal tersebut, pada sekitar Agustus 2011 karyawan notaris di Kabupaten Sleman yang bernama Tuan $\mathrm{AZ}^{1}$ yang bekerja pada kantor Notaris/Pejabat Pembuat Akta Tanah (selanjutnya disebut sebagai PPAT) daerah kerja Kabupaten Sleman, diduga melakukan pemalsuan tanda tangan saksi $\mathrm{X}$ pada bundel blanko permohonan Izin Pemanfaatan Tanah (IPT) di Dinas Perizinan Kabupaten Sleman. Tindakan tersbut dilakukan dengan tujuan pemenuhan syarat formil proses permohonan IPT (Izin Pemanfaatan Tanah) atau dalam proses alih fungsi lahan yang semula diperuntukkan sebagai sawah menjadi tanah pekarangan.

Dugaan pemalsuan tanda tangan saksi $X$ oleh karyawan kantor notaris ditujukan untuk melakukan proses permohonan IPT pada Dinas Perizinan Kabupaten Sleman. Proses permohonan IPT tersebut ternyata tidak diketahui oleh saksi $X$ selaku pemilik 2 (dua) bidang tanah tersebut dan saksi $X$ tidak pernah menyetujui bahwa tanah tersebut akan dilakukan alih fungsi. Berdasarkan data lapangan yang diperoleh oleh penulis, hubungan hukum yang terjadi antara saksi $X$ dan saksi $Z$ didasarkan pada hutangpiutang. Namun, oleh Notaris TA yang bersangkutan dibuatkan akta perikatan jual beli berikut dengan diikuti akta kuasa menjual.

Pada saat saksi $X$ ingin melakukan pelunasan hutang kepada saksi $Z$ ternyata atas 2 bidang tanah yang penulis uraikan di atas, telah dilakukan peralihan hak atas tanah dan pada September 2013 berdasarkan akta perikatan jual beli yang dibuat pada 19 Agustus 2011 dan izin pemanfaatan tanah yang diberikan oleh Dinas Perizinan Sleman, dan melalui Badan Pertanahan Nasional telah terjadi peralihan hak atau balik nama yang semula pada 2 sertifikat tersebut atas nama saksi $X$ beralih menjadi atas nama ke-2 anak saksi Z. Peristiwa ini diputus di dalam Putusan Pengadilan Negeri Sleman Nomor 88/Pid.B/2019/PN.Smn.

Berdasarkan uraian singkat Penulis di atas, perlu dilakukan kajian secara mendalam baik secara teoritis maupun pada prakteknya terkait bentuk pertanggungjawaban notaris dalam hal terjadi permasalahan yang dilakukan oleh karyawan, terlebih tindakan yang dilakukan tuan AZ tersebut merupakan tindakan yang dilarang oleh undang-undang. Dalam praktik banyak ditemukan, jika ada akta notaris dipermasalahkan oleh para pihak atau pihak ketiga lainnya, maka sering pula notaris ditarik sebagai pihak yang turut serta melakukan atau membantu melakukan suatu tindak pidana, yaitu membuat atau memberikan keterangan palsu ke dalam akta notaris. ${ }^{2}$ Dengan demikian Penulis tertarik untuk melakukan penelitian atas permasalahan/kasus yang terjadi dengan mengangkat judul “Pertanggung Jawaban Hukum Bagi Notaris Atas Tindak Pidana Yang Dilakukan Oleh Karyawan Notaris"

${ }^{1}$ Nama disamarkan

${ }^{2}$ Habib Adjie, Hukum Notariat Di Indonesia Tafsiran Tematik. Terbadap UU NO. 30 Tabun 2004 tentang Jabatan Notaris, Rafika Aditama, Bandung, 2008, hlm. 24. 


\section{Rumusan Masalah}

Berdasarkan uraian pendahuluan di atas, maka dirumuskan permasalahan sebagai acuan penelitian ini yakni, pertama, bagaimanakah pertanggungjawaban Notaris atas tindak pidana yang dilakukan oleh karyawan notaris? Kedua, bagaimanakah perlindungan hukum notaris atas tindak pidana yang dilakukan oleh karyawan notaris?

\section{Tujuan Penelitian}

Tujuan yang ingin dicapai penulis dalam penelitian tesis ini yakni, pertama, untuk mengkaji dan menganalisis bentuk-bentuk pertanggung jawaban baik dari sisi pidana maupun perdata bagi Notaris atas tindak pidana yang dilakukan oleh karyawan Notaris. Kedua, untuk mengkaji dan menganalisis apa saja upaya atau peran yang dapat dilakukan oleh Notaris dalam melakukan tindakan preventif agar karyawan tidak melakukan tindak pidana.

\section{Metode Penelitian}

Jenis penelitian yang dilakukan adalah penelitian hukum empiris. Bahan hukum yang dibutuhkan dalam penelitian ini meliputi bahan hukum primer, bahan hukum sekunder dan bahan hukum tersier. Analisis yang digunakan dalam penelitian ini adalah analisis deskriptif kualitatif, dalam arti bahan-bahan hukum yang terkumpul diuraikan dalam bentuk narasi yang tersusun secara sistematis, logis, dan merupakan hasil dari proses interpretasi peneliti terhadap bahan hukum yang dihasilkan berdasarkan dasar filosofis mengenai pertanggungjawaban hukum bagi notaris atas tindak pidana yang dilakukan oleh karyawan Notaris. Bentuk penyajian data/bahan hukum yang sering dilakukan adalah teks naratif. Setelah bahan hukum disajikan, langkah berikutnya adalah menarik kesimpulan berdasarkan reduksi data/bahan hukum dan penyajian data/bahan hukum yang dilakukan.

\section{Hasil Penelitian dan Pembahasan}

\section{Pertanggungjawaban Notaris atas Tindak Pidana yang Dilakukan oleh Karyawan Notaris}

Keterlibatan perkerja kantor notaris/karyawan meliputi, pembuatan akta secara teknis artinya menyiapkan akta-akta yang telah di konsep oleh notaris, kemudian merapikan berkas-berkas akta, mengkomunikasikan dengan pihak atau klien, atau seperti dalam ketentuan Pasal 16 UUJN dalam membantu notaris dalam melakukan pekerjaannya adalah sebagai berikut:
a. Membuat suatu daftar akta (reportorium);
b. Membuat bendel minuta akta menjadi satu bendel;
c. Membuat buku daftar waarmerking, daftar legaslisasi, dan daftar surat lain yang diwajibkan undang-undang;
d. Membuat buku daftar protes;
e. Mencatat dalam repotorium tanggal pengiriman daftar wasiat setiap bulan; dan
f. Membuat buku daftar klaper untuk para penghadap, legalisasi dan waarmerking. 
Tidak jarang biasanya dalam melakukan pekerjaannya tersebut, untuk mempercepat administrasi serta pengurusan, karyawan melakukan cara-cara yang melanggar hukum, suatu misal, pemalsuan surat atau dokumen. Pemalsuan dilakukan pada isi surat atau dokumen, pemalsuan tanda tangan, dan lain sebagainya. Tindakan karyawan tersebut dapat menyeret Notaris sebagai pemberi kerja dalam suatu masalah hukum. ${ }^{3}$

Sebuah tanda tangan dalam akta yang dilakukan dengan meniru tanda tangan seseorang di mana orang tersebut tidak ada, atau tanpa ada persetujuan orang yang bersangkutan dapat dikategorikan bahwa tanda tangan orang tersebut tidak benar. ${ }^{4} \mathrm{Di}$ dalam buku kejahatan pemalsuan surat yang ditulis oleh Adami Chazawi di sebutkan bahwa dalam Arrest HR (14-4-1913) yang menyatakan bahwa:5 "barang siapa yang di bawah suatu tulisan membubuhkan tanda tangan orang lain sekalipun atas perintah dan persetujuan orang tersebut telah memalsukan tulisan itu"

Oleh karena itu merujuk pada Putusan Pengadilan Negeri Sleman Nomor 88/Pid.B/2019/PN.Slmn, diketahui bahwa Tuan AZ telah melakukan pemalsuan pada beberapa dokumen surat yang mana digunakan sebagai permohonan IPT, antara lain:

a. 1 buah surat yang ditujukan kepada Bupati Sleman melalui Kepala Dinas Pengendalian Pertanahan Daerah Kabupaten Sleman atas nama saksi X;

b. 1 bundel proposal pembangunan gudang di wilayah kabupaten Sleman tertera di bawah Agustus 2011;

c. 1 lembar surat kuasa dari saksi $X$ kepada saksi Sukirno khusus untuk dan atas nama pemberi kuasa guna mengajukan permohonan IPT di kantor dinas pekerjaan umum dan perumahan kabupaten Sleman dan segala urusan tersebut tertanggal 31 Juli 2011.

Dalam keterangan yang diperoleh di muka persidangan, alasan Tuan AZ melakukan hal demikian dikarenakan, terdapat pernyataan atau kalimat yang dituangkan dalam akta autentik perikatan jual beli yang dibuat dihadapan notaris yang pada pokoknya menyatakan, "Bahwa kedua tanah tersebut di atas pada saat ini sedang dimohonkan Izin Pemanfaatan Tanah (IPT) di Kantor Pelayanan Perizinan Pemerintah di Kabupaten Sleman dengan berkas permohonan nomor 0083xx.xx.xx tertanggal 04-082011 (empat agustus dua ribu sebelas)"

Setelah akta perikatan jual beli tersebut ditandatangani oleh para pihak (saksi $X$ dan saksi Z) di kantor notaris Tuan TA Yogyakarta. Tuan AZ mendapatkan perintah dari notaris (atasan) kepada Tuan AZ (karyawan) untuk melakukan segala proses pengurusan akta-akta tersebut sampai dengan terbitnya sertipikat hak atas tanah atas nama Saksi Z.

Bahwa pernyataan tersebut diatas, dibenarkan oleh Tuan AZ sebagaimana dinyatakan dalam persidangan pada tahap pemeriksaan Tuan AZ yang mana sang notarislah yang memberikan tugas untuk membuat permohonan IPT, termasuk dokumen pendukung proses IPT. Akan tetapi, notaris yang bersangkutan tidak memberikan perintah untuk melakukan tanda tangan pada dokumen-dokumen permohonan IPT.

3 Achmad Arif Kurniawan, "Pertanggungjawaban Pidana Notaris Dalam Hal Karyawan Melakukan Tindak Pidana Pemalsuan Surat”, Jurnal Hukum Magister Ilmu Hukum Dan Kenotariatan, 2016, hlm 4.

${ }^{4}$ Adami Chazawi, Kejahatan Mengenai Pemalsuan, RajaGrafindo Persada, Jakarta, 2005, hlm. 100.

${ }^{5}$ Ibid. 
Melihat keterangan yang diperoleh di persidangan, Mahrus Ali memberikan pendapat bahwa berdasarkan yurisprudensi Mahkamah Agung 1965, disebutkan bahwa mengenai pembuatan surat palsu yang diketahui dan disetujui oleh orang-orang yang berhak pun tetap dikualifikasikan sebagai pembuatan surat palsu, apalagi jika tidak diketahui pemiliknya. Hal ini karena orientasi dibuatnya ketentuan ini adalah untuk melindungi kepentingan publik, sehingga jangan sampai orang melakukan tindakantindakan pemalsuan surat. 6

Notaris memikul tanggung jawab yang diberikan oleh klien kepadanya dan biasanya dalam melakukan tugas pekerjaannya notaris dibantu oleh para karyawan. Adanya kesalahan dalam melakukan pekerjaan oleh pegawai notaris yang menyebabkan kerugian kepada klien notaris atau pihak ketiga menjadi tanggung jawab notaris. Selanjutnya notaris dapat menuntut pertanggungjawaban pegawainya, baik secara pidana maupun perdata. Belum lazim terjadi notaris menuntut pertanggungjawaban dari pegawainya, ${ }^{7}$ namun demikian perbuatan melawan hukum oleh pegawai ini kadang dijadikan alasan untuk melakukan pemutusan hubungan kerja. ${ }^{8}$

Hans Kelsen, membagi pertanggungjawaban menjadi 4 macam, yaitu: ${ }^{9}$

a. Pertanggungjawaban individu yaitu seorang individu bertanggung jawab terhadap pelanggaran yang dilakukannya sendiri;

b. Pertanggungjawaban kolektif berarti bahwa seorang individu bertanggung jawab atas suatu pelanggaran yang dilakukan oleh orang lain;

c. Pertanggungjawaban berdasarkan atas kesalahan yang berarti bahwa seorang individu bertanggung jawab atas pelanggaran yang dilakukannya karena sengaja dan diperkirakan dengan tujuan menimbulkan kerugian; dan

d. Pertanggungjawaban mutlak yang berarti bahwa seorang individu bertanggung jawab atas pelanggaran yang dilakukannya karena tidak sengaja dan tidak diperkirakan.

Pertanggungjawaban mengandung asas kesalahan (asas culpabilitas), yang didasarkan pada keseimbangan monodualistik bahwa asas kesalahan yang didasarkan pada nilai keadilan harus disejajarkan berpasangan dengan asas legalitas yang didasarkan pada nilai kepastian. Walaupun konsep berprinsip bahwa pertanggungjawaban pidana berdasarkan kesalahan, namun dalam beberapa hal tidak menutup kemungkinan adanya pertanggungjawaban pengganti (vicarious liability) dan pertanggungjawaban yang ketat (strict liability). Masalah kesesatan (error) baik kesesatan

6 Mahrus Ali, keterangan saksi ahli dalam tahap pembuktian pada 08-06-2019 di Pengadilan Negeri Sleman.

${ }^{7}$ Contoh kasus di mana Notaris Notaris mengadukan pegawainya secara pidana atas perbuatan melawan hukum menggelapkan uang titipan klien Notaris. Lihat Susanto, "Tanggung Jawab Notaris Atas Tindakan Karyawannya (Analisis Putusan Pengadilan Negeri Batam Nomor: 926/Pid.B/2016/PN.BTM), Tesis Universitas Indonesia, Program Magister Kenotariatan, Jakarta, Januari 2018.

8 Berdasarkan Putusan Mahkamah Konstitusi Nomor 012/PUU/1/2003, pemberi kerja tidak dapat menggunakan alasan pemutusan hubungan kerja karena adanya kesalahan berat sebagaimana dimaksud dalam Pasal 158 dan 159 UU Ketenagakerjaan, yang dinyatakan tidak mempunyai kekuatan hukum mengikat. Untuk itu diperlukan adanya putusan pidana yang telah mempunyai kekuatan hukum mengikat. Lihat Moch. Syaufi Syamsuddin, Hukum Acara Penyelesaian Perselisihan Hubungan Industrial, Sarana Bhakti Persada, Jakarta, 2005, hlm $115-116$ hlm. 140 .

${ }^{9}$ Hans Kelsen, Terjemahan Raisul Mutaqien, Teori Hukum Murni, Nuansa \& Nusamedia, Bandung, 2006, 
mengenai keadaannya (error facti) maupun kesesatan mengenai hukumnya sesuai dengan konsep alasan pemaaf sehingga pelaku tidak dipidana kecuali kesesatannya itu patut dipersalahkan. ${ }^{10}$

Dalam hal notaris sebagai pemberi kerja (atasan) memiliki tanggung jawab kepada karyawan atau karyawan yang membantunya dalam menjalankan tugas dan jabatannya, baik dalam mempersiapkan surat-surat berkaitan dengan akta yang akan di buat oleh notaris atau dalam hal lainnya yang berkaitan dengan jasa notaris. Artinya, notaris bertanggung jawab penuh terhadap apa yang dilakukan oleh karyawan. Dalam hubungan yang bersifat koordinatif, tanggungjawab atas pekerjaan yang dilakukan merupakan tanggung jawab langsung dari yang melakukan, namun notaris dapat dimintakan keterangan sehubungan dengan terjadinya perbuatan melawan hukum oleh orang yang melakukan pekerjaan di kantornya. Sedangkan dalam hubungan yang bersifat sub ordinasi, notaris sebagai pemberi kerja, bertanggung jawab atas yang dilakukan oleh pegawainya. ${ }^{11}$

Pertanggungjawaban pidana notaris apabila karyawan terbukti melakukan tindak pidana pemalsuan surat adalah notaris dapat terjerat penyertaan dalam tindak pidana tersebut, dikarenakan notaris seharusnya memahami dan mengetahui apa yang dikerjakan oleh karyawan. Jika notaris tidak mengetahui apa yang dilakukan oleh karyawannya, maka dapat dikatakan notaris selaku pemberi kerja telah melakukan kelalaian (culpa) dalam melaksanakan tugas dan jabatannya. Kelalaian (culpa) terletak antara sengaja dan kebetulan, bagaimanapun juga culpa dipandang lebih ringan dibanding dengan sengaja, oleh karena itu delik culpa, merupakan delik semu (quasideliet) sehingga diadakan pengurangan pidana.

Menurut Habib Adjie, dalam perkara pidana seringkali notaris dijerat dengan pasal dalam Kitab Undang-Undang Hukum Pidana (KUHP) sebagai berikut:12

a. Membuat surat palsu/yang dipalsukan dan menggunakan surat palsu/yang dipalsukan (Pasal 263 ayat (1) dan (2) KUHP);

b. Melakukan pemalsuan terhadap akta otentik (Pasal 264 KUHP)

c. Menyuruh mencantumkan keterangan palsu dalam akta otentik (Pasal 266 KUHP);

d. Melakukan, menyuruh melakukan, turut serta melakukan (Pasal 55 Jo. Pasal 263 ayat (1) dan (2) KUHP atau Pasal 264 atau Pasal 266 KUHP)

e. Membantu membuat surat palsu/atau yang dipalsukan dan menggunakan surat palsu/yang dipalsukan (Pasal 56 ayat (1) dan (2) Jo. Pasal 263 ayat (1) dan (2) KUHP atau Pasal 264 atau Pasal 266 KUHP).

Apabila karyawan melakukan tindak pidana pemalsuan surat, maka notaris dapat dijerat pada Pasal 55 Jo. Pasal 263 ayat (1) dan (2) Kitab Undang Undang Hukum Pidana atau Pasal 264 atau Pasal 266 Kitab Undang Undang Hukum Pidana, serta Pasal 56 ayat (1) dan (2) Jo. Pasal 263 ayat (1) dan (2) Kitab Undang Undang Hukum Pidana atau Pasal

10 Barda Nawawi Arief, Masalah Penegakan Hukum dan Kebijakan Penanggulangan Kejahatan, Citra Aditya Bakti, Bandung, 2001, hlm. 23.

${ }_{11}$ Dalam istilah hukum, pertanggung jawaban karena hubungan sub ordinasi antara pemberi kerja dengan karyawannjya disebut sebagai Vicarious Liability.

${ }^{12}$ Ibid. 
264 atau Pasal 266 Kitab Undang Undang Hukum Pidana. Pasal 55 dan Pasal 56 angka (1) dan angka (2) Kitab Undang Undang Hukum Pidana yang merumuskan mengenai penyertaan dalam tindak pidana dapat di kenakan kepada notaris apabila karyawan melakukan tindak pidana. Penyertaan pada suatu kejahatan terdapat apabila dalam satu tindak pidana tersangkut beberapa orang atau lebih dari seorang. Hubungan tersebut: ${ }^{13}$

a. beberapa orang bersama-sama melakukan satu tindak pidana;

b. mungkin hanya satu orang yang mempunyai kehendak dan merencanakan tindak pidana, akan tetapi tindak pidana tersebut tidak dilakukan sendiri, tetapi ia mempergunakan orang lain untuk melakukan tindak pidana tersebut; dan

c. dapat juga terjadi bahwa seorang saja yang melakukan tindak pidana, tetapi ia mempergunakan orang lain itu dalam melaksanakan tindak pidana.

Melihat duduk perkara yang menjadi fokus penelitian, pertimbangan hakim dalam memutus perkara tanpa melibatkan pertanggung jawaban notaris TA sebagai pimpinan antara lain permohonan IPT tersebut terdiri dari 13 syarat yang mana kesemuanya merupakan satu kesatuan dalam proses permohonan IPT, sehingga walaupun apa yang telah dilakukan Tuan AZ berupa menandatangani 4 surat tersebut, tanpa diikuti dengan syarat yang lainnya, maka proses permohonan IPT tersebut tidak dapat diberikan ijin oleh Dinas Perizinan Pemerintah Daerah Kabupaten Sleman dan majelis hakim berpendapat bahwa alasan tersebut tidak menghilangkan kesalahan Tuan AZ yang telah menandatangani dokumen dengan menggunakan nama saksi $X$ tanpa sepengetahuannya.

Kemudian, dalam pertimbangannya majelis hakim menemukan fakta bahwa Tuan AZ yang mana merupakan karyawan dari notaris TA di kabupaten Sleman, yang diberikan tanggung jawab untuk mengurus proses pengajuan IPT atas tanah yang menjadi objek jual beli antara saksi $X$ dan saksi $Z$. Bahwa perintah yang diterima oleh Tuan AZ adalah untuk melakukan pengurusan sampai dengan IPT tersebut dikeluarkan dinas terkait dan berdasarkan pengakuan Tuan AZ di muka persidangan pada saat proses pemeriksaan, notaris sebagai pimpinan kantor tidak pernah memberikan perintah/memerintahkan Tuan AZ untuk menandatangani dokumen tersebut tanpa memberitahukan saksi $\mathrm{X}$ terlebih dahulu.

Berkaitan dengan perintah yang diterima, pada saat proses pemeriksaan yang dimaksud perintah atasan oleh Tuan $\mathrm{AZ}$ merupakan keterangan yang berdiri sendiri karena tidak di dukung oleh alat bukti lain dan ketika diberikan kesempatan untuk membuktikan, Tuan AZ (karyawan) tidak mengajukan satupun bukti yang menguatkan bahwa Tuan AZ (karyawan) menjalankan perintah dari atasannya/notaris. Kasus ini telah diputuskan oleh hakim bahwa Tuan AZ dinyatakan bersalah dan melakukan pelanggaran terhadap Pasal 263 Kitab Undang-Undang Hukum Pidana serta dihukum 1 tahun penjara.

Dari rangkaian peristiwa yang telah penulis kemukakan di awal tadi, terlepas dari keputusan majelis hakim di atas seharusnya notaris tersebut yang bersangkutan dapat dimintakan pertanggung jawaban hukum. Sebab menurut penulis dari awal notaris tersebut telah melakukan kesalahan dalam menentukan hubungan hukum antara saksi $\mathrm{X}$

13 Didik Endro P., Hukum Pidana, Khusus untuk mahasiswa Fakultas Hukum Universitas Airlangga, Surabaya, 2007, hlm. 55. 
dan saksi $\mathrm{Z}$ yang mana fakta hubungan hukum yang terjadi di awal adalah hutang piutang, bukan jual beli. Seharusnya bukan PJP yang dibuat melainkan pengakuan hutang. Terlebih lagi dalam perkara ini penulis berpendapat bahwa terdapat beberapa kejanggalan antara lain dalam pengakuan saksi $X$ dimuka persidangan yang menyatakan bahwa dia tidak mengetahui terkait adanya proses IPT artinya notaris TA dalam memperintahkan tuan AZ juga tanpa sepertujuan saksi $X$ sehingga dapat penulis katakan bahwa notaris yang bersangkutan turut serta dalam rangkaian peristiwa ini. Di samping itu dalam hal izin IPT telah diterbitkan oleh Dinas Perizinan, maka seharusnya notaris tersebut mengetahui proses dan prosedurnya karena dalam membuat AJB (Akta Jual Beli) notaris/ PPAT itu berdasar pada PJB Lunas, kuasa menjual dan izin dari Dinas Perizinan terkait perubahan status tanah yang semula tanah sawah berubah menjadi tanah pekarangan.

\section{Perlindungan Hukum Notaris atas Tindak Pidana yang Dilakukan oleh Karyawan Notaris}

Perlindungan hukum bagi notaris secara normatif telah diberikan oleh peraturan perundang-undangan yang berlaku, yaitu:

a. Pembentukan Majelis Pengawas sebagaimana diamanatkan dalam Pasal 67 UUJN dibentuk oleh Menteri, yang terdiri atas 3 unsur, yaitu pemerintah, organisasi Notaris dan akademisi. Pengawasan tersebut meliputi pelaksanaan jabatan Notaris;

b. Mengenai tata cara pengambilan minuta akta dan pemanggilan terhadap Notaris, menurut Pasal 66 UUJN;

c. Nota Kesepahaman antara Kepolisan Negara Republik Indonesa dengan Ikatan Notaris Indonesia, Nomor 01/MOU/PP-INI/V/2006 tentang Pembinaan dan Peningkatan Profesionalisme di Bidang Penegakan Hukum;

d. Surat Keputusan Majelis Pengawas Pusat Nomor C-MPPN.03.10-15 tentang Pemberian atau Penolakan Persetujuan Pemanggilan Notarsi oleh penyidik, penuntut umum atau hakim;

Pemerintah menetapkan perubahan UUJN yang baru dengan salah satunya membentuk lembaga perlindungan hukum yang baru bagi notaris, yaitu Majelis Kehormatan Notaris (MKN). UUJN telah memberikan suatu bentuk perlindungan hukum secara khusus bagi notaris, yang diatur dalam Pasal 66 ayat (1) UUJN, yang menyatakan bahwa:

Untuk kepentingan proses peradilan, penyidik, penuntut umum, atau hakim dengan persetujuan Majelis Kehormatan Notaris berwenang:

a. Mengambil fotokopi Minuta Akta dan/atau surat-surat yang dilekatkan pada Minuta Akta atau Protokol Notaris dalam penyimpanan Notaris; dan

b. Memanggil Notaris untuk hadir dalam pemeriksaan yang berkaitan dengan Akta atau Protokol Notaris yang berada dalam penyimpanan Notaris.

Kehadiran MKN ini merupakan upaya yang dilakukan pemerintah dalam memberikan suatu bentuk perlindungan hukum bagi notaris dalam menjalankan tugas jabatannya sebagai pejabat umum. Sebelumnya kewenangan ini dipegang oleh MPD. Jadi dengan demikian dapat dikatakan bahwa ketentuan dalam Pasal 66 ayat (1) UUJN ini 
merupakan kewenangan mutlak dari MKN yang tidak dimiliki oleh Majelis Pengawas Notaris yang lainnya. Substansi Pasal 66 ayat (1) UUJN ini berlaku terhadap notaris, dengan batasan sepanjang berkaitan dengan tugas dan kewenangan jabatan notaris sebagaimana dinyatakan dalam Pasal 15 UUJN. Ketentuan tersebut hanya berlaku dalam perkara pidana, karena dalam pasal tersebut berkaitan dengan tugas penyidik, penuntut umum dalam ruang lingkup perkara pidana.

Perlindungan hukum selain diberikan oleh undang-undang melalui Majelis Kehormatan Notaris, terdapat perlindungan hukum yang bisa diupayakan oleh notaris sendiri bila terjadi permasalahan terdiri atas: ${ }^{14}$

a. Menguasai hukum secara baik dan benar terhadap semua ketentuan hukum/peraturan perundang-undangan yang ada hubungan tugas dan jabatannya selaku Notaris. Dalam hal demikian adalah hukum kenotariatan yang pada kenyataannya merupakan hutan belantara hukum dalam arti banyak sekali ketentuan hukum/peraturan perundang-undangan yang harus dikuasai setiap Notaris;

b. Berusaha mengejar kebenaran materiil atas rencana akta yang akan dibuat dihadapannya;

c. Notaris jangan hanya sebatas mengandalkan copy paste dalam membuat akta, karena kasus kongkrit yang dihadapi yang merupakan kehendak penghadap/klien belum tentu mad/cocok dengan akta yang akan di copy-paste/ salin-tempel. Dengan kata lain jangan sekali-kali membuat akta tanpa ilmu (ilmu hukum);

d. Notaris jangan sekali - kali sebatas mengandalkan/percaya kepada klien atau penghadap walaupun klien atau penghadap tadi dalah teman dekat, sehingga mempercayakan penandatanganan minuta akta tanpa harus hadir dihadapan Notaris atau Notaris hanya sebatas menyuruh stafnya guna menandatangani munuta akta;

e. Notaris jangan sekali - kali mendasarkan kuasa yang tidak Notariil atau sebatas Surat Kuasa di bawah tangan yang tanpa dilegalisir Notaris atau yang kemudian dipakai sebagai dasar dalam pembuatan akta;

f. Notaris harus cerdas, teliti, cermat dan rapih dalam membuat akta lebih-lebih kalau sudah terkait dengan aspek hukum yang merupakan perbuatan hukum yang dimuat dalam akta. Dalam hal demikian Notaris harus benar-benar cermat dalam arti dikaji ulang jangan sampai kemudian bisa berakibat merugikan pihak yang terkait sehubungan dengan pembuatan hukum yang dimuat dalam akta;

g. Notaris jangan sekali-kali sebatas mengandalkan atau percaya begitu saja terhadap pegawai/staf Notaris walaupun telah diketahui bahwa pegawai atau stafnya tersebut jujur, teliti, amanah dan pandai. Notaris harus tetap meneliti ulang draf atau rencana akta yang ditandatangani.

Berdasarkan aturan normatif mengenai perlindungan hukum baik yang diberikan oleh undang-undang ataupun upaya preventif yang dapat dilakukan oleh notaris, perlindungan hukum harus berdasarkan atas suatu ketentuan dan aturan hukum yang

${ }^{14}$ Berdasarkan pendapat Mulyoto selaku akademisi dan Werda Notaris/PPAT pada 5 Desember 2016, dikutip dari Suhardino, "Tinjauan Yuridis Perlindungan Hukum Bagi Notaris Atas Keterangan, Identitas Dan Atau Dokumen Palsu Yang Disampaikan Oleh Para Pihak Yang Dijadikan Dasar Pembuatan Akta Autentik”, Tesis, Magister Kenotariatan Fakultas Hukum, Universitas Islam Indonesia, Yogyakarta, 2017. 
berfungsi untuk memberikan keadilan serta menjadi sarana untuk mewujudkan kesejahteraan bagi seluruh rakyat. ${ }^{15}$ Perlindungan, keadilan, dan kesejahteraan tersebut ditujukan pada subyek hukum yaitu pendukung hak dan kewajiban, tidak terkecuali bagi seorang notaris. 16

\section{Penutup}

Berdasarkan hasil pemaparan daripada penelitian yang dilakukan oleh penulis, maka dapat disimpulkan bahwa, pertama hubungan antara karyawan dengan notaris merupakan hubungan subordinasi, sehingga bilamana seorang karyawan melakukan pemalsuan surat sehingga dapat mengakibatkan notaris melakukan penyimpangan akan sebuah akta yang dibuatnya sehingga menimbulkan suatu perkara pidana maka notaris dapat dipertanggung jawabkan secara pidana apa yang telah dilakukan oleh karyawan tersebut bilamana memenuhi unsur Pasal 55 jo. Pasal 263 KUHP atau Pasal 264 KUHP. Melihat pada perkara di atas notaris seharusnya dapat dimintakan pertanggungjawaban.

Kedua, bentuk perlindungan hukum yang diberikan oleh undang-undang yakni melalui Majelis Kehormatan Notaris yaitu melakukan pengawasan dan pemeriksaan bagi notaris supaya tetap bekerja secara profesional sesuai dengan undang-undang dan perlindungan hukum yang biasa diupayakan notaris sendiri dalam pembuatan akta autentik atau dalam hal pekerjaan yang dilakukan harus memperhatikan prinsip kehatihatian, ketelitian, serta menjunjung tinggi kejujuran, moralitas serta tidak melupakan profesionalitas.

Saran pada penelitian ini yakni notaris harus cerdas, teliti, cermat dan rapih dalam membuat akta sebagaimana amanat Pasal 16 ayat (1) huruf a UUJN, khususnya terkait dengan aspek hukum berupa perbuatan hukum yang dimuat dalam akta. Dalam hal demikian, notaris harus benar-benar cermat dalam arti harus meneliti ulang agar tidak menimbulkan kerugian bagi pihak yang terkait sehubungan dengan perbuatan hukum yang dimuat dalam akta. Notaris jangan sekali-kali sebatas mengandalkan atau percaya begitu saja terhadap pegawai/staf notaris walaupun telah diketahui bahwa pegawai atau stafnya tersebut jujur, teliti, amanah dan pandai. Notaris harus tetap meneliti ulang draft pekerjaan karyawan tersebut atau rencana akta yang ditandatangani.

\section{Daftar Pustaka}

\section{Buku}

Adjie, Habib, Hukum Notariat Di Indonesia Tafsiran Tematik Terhadap UU NO, 30 Tahun 2004 tentang Jabatan Notaris, Rafika Aditama, Bandung, 2008.

Meneropong Khasanah Notaris dan PPAT Indonesia, PT Citra Aditya Bakti, Bandung, 2009

Arief, Barda Nawawi Masalah Penegakan Hukum dan Kebijakan Penanggulangan Kejahatan, Citra Aditya Bakti, Bandung, 2001.

${ }^{15}$ Satjipto Raharjo, Ilmu Hukum, Citra Aditya Bakti, Bandung, 2000, hlm. 53. hlm. 83 .

${ }^{16}$ Habib Adjie, Meneropong Khasanah Notaris dan PPAT Indonesia, PT Citra Aditya Bakti, Bandung, 2009, 
Chazawi, Adami, Kejahatan Mengenai Pemalsuan, Raja Grafindo Persada, Jakarta, 2005.

Kelsen, Hans, Teori Hukum Murni, Nuansa \& Nusamedia, Bandung, 2006.

P., Didik Endro, Hukum Pidana, Khusus untuk mahasiswa Fakultas Hukum Universitas Airlangga, Surabaya, 2007.

Raharjo, Sajtipto, Ilmu Hukum, Citra Aditya Bakti, Bandung, 2000.

\section{Tugas Akhir}

Susanto, "Tanggung Jawab Notaris Atas Tindakan Karyawannya (Analisis Putusan Pengadilan Negeri Batam Nomor: 926/Pid.B/2016/PN.BTM)"', Tesis, Universitas Indonesia, Program Magister Kenotariatan, Jakarta, 2018.

Suhardino, "Tinjauan Yuridis Perlindungan Hukum Bagi Notaris Atas Keterangan, Identitas Dan Atau Dokumen Palsu Yang Disampaikan Oleh Para Pihak Yang Dijadikan Dasar Pembuatan Akta Autentik", Tesis, Magister Kenotariatan Fakultas Hukum, Universitas Islam Indonesia, Yogyakarta, 2017.

\section{Jurnal}

Kurniawan, Achmad Arif, "Pertanggungjawaban Pidana Notaris Dalam Hal Karyawan Melakukan Tindak Pidana Pemalsuan Surat", Jurnal Hukum Magister Ilmu Hukum Dan Kenotariatan, 2016.

\section{Peraturan Perundang-Undangan}

Undang-Undang Nomor 2 Tahun 2014 tentang Jabatan Notaris

Kitab Undang-Undang Hukum Pidana

\section{Putusan Pengadilan}

Putusan Pengadilan Negeri Sleman Nomor 88/Pid.B/2019/PN.Smn 